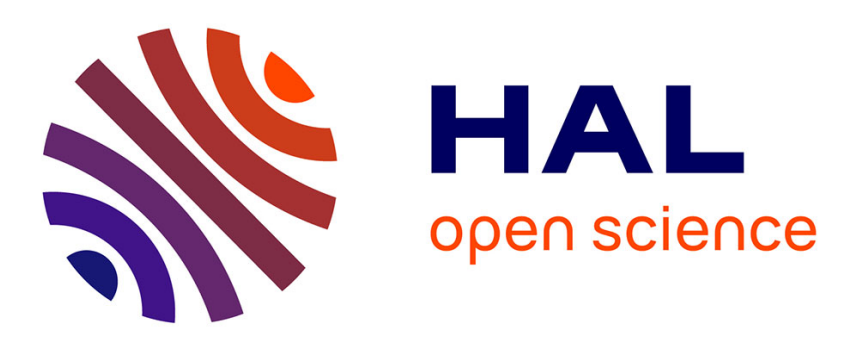

\title{
Medical sociology and the biological body: where are we now and where do we go from here?
}

Simon J. Williams

\section{To cite this version:}

Simon J. Williams. Medical sociology and the biological body: where are we now and where do we go from here?. Health:, 2006, 10 (1), pp.5-30. 10.1177/1363459306058984 . hal-00571417

\section{HAL Id: hal-00571417 \\ https://hal.science/hal-00571417}

Submitted on 1 Mar 2011

HAL is a multi-disciplinary open access archive for the deposit and dissemination of scientific research documents, whether they are published or not. The documents may come from teaching and research institutions in France or abroad, or from public or private research centers.
L'archive ouverte pluridisciplinaire HAL, est destinée au dépôt et à la diffusion de documents scientifiques de niveau recherche, publiés ou non, émanant des établissements d'enseignement et de recherche français ou étrangers, des laboratoires publics ou privés. 


\author{
Simon J. Williams \\ University of Warwick, UK
}

\begin{abstract}
In this article I pose the question, 'where is the biological body in medical sociology today?' The first part of the article provides a selective corporeal balance sheet of where we are now in medical sociology, with particular reference to social constructionist and phenomenological approaches and their respective stances or takes on the (biological) body. The subsequent section considers where we might profitably be going in the future in terms of bringing the biological body (back) in, and the broader issues this raises for the sociological enterprise as a whole. Various problems associated with this evolving project and merits of other recent approaches, such as the sociology of translation, are considered. The article concludes with some further thoughts and reflections on these matters, including a revisiting of relations between the sociology of the body and medical sociology in the light of these debates.
\end{abstract}

KEYWORDS body; biology; medicine; practice; realism

ADDRESS Simon J. Williams, Department of Sociology, University of Warwick, Coventry CV4 7AL. [E-mail: s.j.williams@warwick.ac.uk]

ACKNOWLEDGements Thanks to Bryan Turner, among others, for constructive comments on an earlier draft of this article. Thanks also to Lynda Birke for various discussions over the nature and status of the biological body, and to Alan Radley and the anonymous reviewers of this article for their encouragement and suggestions.

\title{
Introduction
}

In this article I pose the seemingly simple, yet on closer inspection complex and contested question, 'where is the biological body in medical sociology today?' This may sound an odd question to ask a sociological audience. It also, of course, begs a series of further questions, not least as to why the biological body should matter to sociologists anyway, particularly those with little or no professed interest in body matters, biological or otherwise, and 
what this might entail should, per chance, it turn out to be an important question after all.

The body is very much alive and kicking in recent sociological scholarship and debate - part and parcel of broader corporeal trends - both inside and outside the academy. On the one hand, this is surely welcome and long overdue, challenging many former assumptions and problematic divisions along the way. On the other hand, I venture, it has created its own tensions if not outright problems. The body, it seems, is everywhere and nowhere today - a victim of its own success perhaps? A paradox, moreover, lies at the heart of these corporeal debates. For all this alleged interest, the body, in certain (dominant) strands of thinking at least, remains peculiarly disembodied, disembowelled, disincarnated or dematerialized (Birke, 1999), call it what you will; a body allowed (back) in (Frank, 1991), so to speak, but one which is credited more or less wholesale to the social side of the balance sheet in doing so. Hence the pertinence of the seemingly rogue or repressed question posed above, is there a place for the biological body in all this?

Medical sociology, or the sociology of health and illness as it is now more commonly known, ${ }^{1}$ is certainly a good place to examine these issues, dealing as it does with matters of life and death. To the extent moreover that professional rivalries are evident here (Strong, 1979), not least concerning the nature and status of biomedicine, this may indeed provide a useful window looking to other important dimensions of these debates and struggles over the body today in sociology and beyond. To concede a biological body, in other words, may come at too high a price for some (medical) sociologists.

The article is divided into two main parts. The first provides a somewhat selective corporeal balance sheet of where we are now in medical sociology, with particular reference to social constructionist and phenomenological approaches and their respective stances or takes on the (biological) body. The second builds on these corporeal debates, considers where we might profitably be going in the future in terms of bringing the biological body (back?) in, and the broader issues this raises for the sociological enterprise as a whole. Various problems associated with this project are also considered - particularly in terms of the (un)knowable body and the complexity of these biology-society relations themselves - alongside other recent attempts to resolve these issues through the sociology of translation and the enactment of reality in practice. The article concludes with some further thoughts and reflections on these matters, including a revisiting of relations between the sociology of the body and medical sociology in the light of these debates. Where are we now then as far as the (biological) body is concerned?

\section{Current state of play: a corporeal balance sheet}

Medical sociology, in many respects, has always been about bodies: sick bodies; healthy bodies; medicalized bodies; disabled bodies; reproductive 
bodies; dying bodies; dead bodies; and so on. The historical development of medical sociology, however, has meant that it is only relatively recently, thanks in no small part to the upsurge of interest in body matters both inside and outside the academy, that the body has become an explicit topic of discussion and debate. Feminists, perhaps, may object to any such reading, pointing out that women's struggle over bodies, particularly with respect to medicine, predates these current corporeal concerns and (malestream) preoccupations: our bodies, ourselves (Boston Women's Health Collective, 1973). Even here, however, ambivalence about bodies, if not outright somatophobia or biophobia, has been evident within past feminist scholarship and debate (Spelman, 1988): something, in keeping with the broader corporeal trends, which is only now being redressed (see for example Birke, 1999, 2003; Fausto-Sterling, 1992, 2000, 2003).

Two main strands of thinking on body matters, in keeping with broader debates on the body in sociology today, are now evident in medical sociology.

\section{Social constructionism and the discursive body: Foucault and beyond}

Strands of social constructionist thought have of course been deployed for many years in medical sociology, particularly within what one may term 'conventional' medicalization critiques (Conrad, 1992). The Foucauldian legacy, however, has taken this much further through a new more thoroughgoing medicalization critique in which former acknowledgement or acceptance of an underlying 'natural' or 'bio-physical' reality (and associated notions such as the traditional disease-illness distinction) are cast in doubt if not abandoned altogether. The body and disease, in this respect, become (mere) discursive matters, the product that is to say of strategic, shifting, historically contingent configurations of power/knowledge. The 'solid', 'visible' body, Foucault (1973: 3) famously proclaims in Birth of the Clinic, 'is only one way - neither the first nor the most fundamental - in which one spatializes disease. There have and will be other distributions of illness.' It is not simply therefore, as Lupton (1997: 107) puts it, a question of:

stripping away medicine as a dominant frame of reference to reveal the 'true' body, as most orthodox critics would argue. From the Foucauldian perspective, 'demedicalizing' the body, or viewing it through alternative frames of reference that are not medical, may well lead to different, but not more 'authentic' modes of subjectivity or embodiment.

Foucault's work, as this suggests, has been hugely influential within medical sociology, providing a systematic approach to medical institutions, government and the human body (Turner, 1995: 1). Through critical explorations of the relationship between power/knowledge and the body, including the 'anatamo-politics' of the human body and the 'bio-politics' of the population (Foucault, 1979), a number of important insights have emerged in 
medical sociology over the past two decades: insights, that is to say, concerning the production, regulation and representation of bodies within the context of disciplinary surveillance and the medical regimen (Turner, 1997: xv).

Armstrong, for example, himself a key exponent of the Foucauldian line in medical sociology, has drawn attention to the various ways in which the human body has been subjected to a:

... more complex, yet perhaps more efficient, machinery of power which, from the moment of birth (or more correctly, from the time of registration at an antenatal clinic) to death, has constructed a web of investigation, observation and reordering around individual bodies, their relationships and their subjectivity, in the name of health. (1983: 112)

'Surveillance Medicine', moreover, it is claimed, has now eclipsed 'Hospital Medicine' (Armstrong, 1995): a transition symbolized, in the current era of health promotion, by the strategic shift to a spatio-temporal calculus of risk factors, crystallized in the moral pursuit or 'imperative' of health (Lupton, 1997) through lifestyles and 'care of the self'. The regulation of bodies, in these and other ways, is now primarily achieved through new forms of 'governmentality' - a regime that links self-subjection to societal regulation (Turner, 1997: xv). While it may seem difficult, in short, given these latter-day perspectives, to take a definitive stance on issues of medicalization, awareness of these very difficulties, Lupton (1997: 108) assures us, is itself an 'important outcome that emerged from the entrée of Foucauldian perspectives into the debate'.

Feminist writings on the body have also critically appropriated and deployed these Foucauldian insights (Sawiki, 1991), highlighting the construction and regulation of women's bodies in and through medical discourse and in various health care settings (Eckermann, 1997; Harding, 1997). This in turn has served to more or less thoroughly problematize essentialist notions of the 'sexed' body, in medicine and elsewhere, thereby providing important new opportunities for resistance through a feminist body/politics in which bodies may be written if not lived differently (Jacobus et al., 1990).

Other strands of postmodern thinking on health have taken this Foucauldian message much further, opening up a series of more or less promising new positions along the way. Nicholas Fox (1999), for example, a forceful exponent of this postmodern stance in medical sociology, condemns the modernist underpinnings of existing sociological and medical approaches to the body, in sickness and in health. Postmodernism, he claims, borrowing from the likes of Foucault, Derrida, Deleuze and Guattari, Cixous and others, promises to 'open up' the discourses which 'fabricate' our bodies and territorialize us, through various forms of disciplinary expertise, in the name of health and illness. The discourses of medicine and its 'collaborators' within the modernist human sciences, it is claimed, seek to: '... territorialize us as "organisms" - bodies-with-organs (Deleuze and 
Guattari, 1984, 1989), doomed to face the ministrations of these disciplines - to "health", "beauty" to a "full and active life", to patience in the face of the failure of senses and memory, to accept, to be, never to become other' (Fox, 1999: 6; emphasis in original). Biomedicine, in other words, constrains and closes down other more promising options, possibilities, choices, rendering us, in effect, (fixed) bodies with organs vis-a-vis other more nomadic, deterritorialized, postmodern forms of subjectivity and embodiment which, Fox claims, take us 'beyond' health.

For all its promise and potential, however, a number of problems remain with these positions. Perhaps the main problem here is that the world, and the body and disease within it, becomes equated or conflated with our discursive constructions, with 'discovery' traded for 'fabrication': a 'writing out', in effect, through the very process of 'writing in'. The construction of what, therefore, remains largely unanswered; an impossible question to answer, in fact, from this viewpoint. We may indeed go further, harking back to a point raised in the introduction, and state that the body on offer here, or perhaps more correctly the bodies on offer here (for there are as many as we care to construct), are peculiar bodies indeed: disembodied, disembowelled, disincarnated, dematerialized, deracinated, ethereal bodies, based on a 'surface' theory that is only 'skin deep' (Birke, 1999). Constructionists, of course, may reasonably retort that the 'extra-discursive' aspects of bodies and the world they inhabit are not in fact denied. They can only be known, however, through this or that discursive frame of reference or configuration of power/knowledge. This is fair enough. All too often, however, the slide from this perfectly reasonable, weaker claim, to stronger endorsements of the constructionist line, proves tempting if not irresistible; one in which the discursive and the extra-discursive are collapsed anew with no attempt to theorise these issues both ways, so to speak. Our social constructions aren't quite as arbitrary as we care to think. Bodies surprise us, they betray us in all sorts of ways that render our constructions of them problematic: it's two-way traffic in short, with many surprises en route (see also Murphy's [2002] two-way musings on these relations). ${ }^{2}$

A further paradox arises here, namely that is only by virtue of our evolved biological capacities for tool and language use that constructionists are able to deny or downplay the biological as little more than a fabrication: selfdeception or self-deceit indeed. What this amounts to, in the final analysis, is not so much the overcoming of biological reductionism, as its inversion through a new form of reductionism or 'discourse determinism' in which all is reduced to the social, qua power/knowledge. In doing so, the biological is itself written out or rendered unimportant, except as yet another ('rival') body of power/knowledge. An infinite regress results therefore which has us all precariously perched if not falling into the 'abyss of relativism', given the absence of any independent court of appeal or grounds upon which to arbitrate between different knowledge claims or versions of reality (Bury, 1986). 


\section{The lived body: phenomenology and beyond}

Here we arrive at the second main way in which the body is evident in medical sociology today, namely through a more fully embodied perspective on matters of health and illness which lays the Cartesian ghost of mind-body dualism to rest once and for all. The emphasis here, again echoing broader debates within the sociology of the body, is on the moving, thinking, feeling, pulsing, body; the lived body as a mindful, intentional site of on-going experience, a spontaneous synthesis of powers, and the very basis of our being-in-the-world (Merleau-Ponty, 1962). This is an approach, as Leder puts it, which does not so much replace the biological account, as place it within a 'broader perspective'. The:

Anatomy and physiology of the lived body are always intertwined with the body's intentionality in ways that undermine facile claims of priority. Just as our physical structure lays the groundwork for our mode of being-in-the-world, so our interactions with this world fold back to reshape our body in ways conducive to health and illness. A medicine of the lived body dwells in this intertwining. (1998: 125)

It is still all too easy, of course, to miss, neglect or downplay this intertwining, even when researching the lived body. A variety of studies may be pointed to, nonetheless, which do indeed dwell on/in this intertwining. Freund's (1990) work, for example, is instructive here on a number of counts. The emotionally 'expressive' body, he argues, provides a 'common ground' for the sociology of emotions and the sociology of health and illness. In particular, this helps us understand more clearly how social structure affects health deep within the recesses of the human body. Differing modes of emotional being, in effect, are differing ways of feeling empowered or disempowered; feelings very much linked to people's conditions of existence throughout their embodied biographies. It is here at this embodied nexus, Freund argues, that:

'External' social structural factors such as one's position in different systems of hierarchy or various forms of social control can influence the conditions of our existence, how we respond and apprehend these conditions of existence and our sense of embodied self. These conditions can also affect our physical functioning. (1990: 461)

The argument here then is for a subtle and sophisticated form of socially 'pliable' biology, which accords existential modes of being a central role in linking the health and illness of the embodied agent with wider structures of power and domination, civilization and control. In doing so, moreover, some promising links are provided with broader agendas concerning inequalities in health, particularly work on the 'socio-biological translation' (Tarlov, 1996; Wilkinson, 1996) and on-going research in the life-events and illness paradigm (Brown and Harris, 1989) - see also Dickens (2000) on how capital is modifying human biology in its own image, and Blaxter (2003) on the 'synthesis' of biology, social class and inequalities in health through 'health capital'. 
Monaghan (2003), in contrast, takes a somewhat different line, highlighting ethnoscientific understandings and social constructions of the supposed bodybuilding, steroids and violence connection; accounts that challenge yet incorporate arguments concerning steroid, mood and behavioural effects. Rather than writing the biological cum hormonal body out, Monaghan shows, these ethno scientific accounts underscore the social significance of biology and bodily health once they are conceptualized in non-reductionist terms. Respondents endeavouring to build 'better' physical bodies, in this respect, offered a 'coherent and integrated account of the ways in which "male" sex hormones may be implicated in the social in non-determinate ways' (2003: 155). Finding a place for the biological, in short, was relatively unproblematic for these respondents; one shorn of reductionist baggage and media hype concerning the supposed 'roid-rage connection'.

The sociology of chronic illness has also benefited enormously from a fuller engagement with embodiment in recent years. Although not explicitly excluded, the body has nonetheless remained 'theoretically elusive' in much of this past literature, as Kelly and Field (1996: 243) note, constantly gliding out of view through an overemphasis on 'meaning' at the expense of the 'restrictions and discomforts of illness and disability'. The call therefore is not simply for an approach to the study of chronic illness which explicitly focuses on the body, but one which incorporates both social and biological facts in doing so. Bodies, it is only too apparent, "change in chronic illness'. Chronic illness also involves 'changes in self-capacities which are reciprocal to bodily experiences, feelings and actions' (1996: 247; emphasis in original). The body, it follows, is central here because 'the biological bases of experience as perceived by self and others have very important effects on the construction of self and identity' (1996: 248). The relationship between self and identity, in other words, is a 'social process which alters through time, as the bodily contingencies change' (1996: 248-9). Biological and physical facts, in short, are sociologically significant because: 'a) they impinge directly on the self; $b$ ) they provide signals for identity construction, and; c) they act as limiting factors for the sufferer' (1996: 251) - see also Millward and Kelly (2003) on relations between body, self and the material world.

Other work on issues such as pain and emotion (Leder, 1990; Williams and Bendelow, 1998), and illness narratives (Kleinman, 1988) raise similar embodied themes and corporeal concerns. Frank (1996: 58), for example, notes how odd the idea of body as 'surface' or 'text' is for someone who suffers from cancer: illness, he states, means living with the body, experiencing it through a 'shifting synthesis of this perpetually spiralling dialectic of flesh, inscription and intention' (see also Frank, 1995). 'Culture', from this viewpoint, fills the existential space between the 'immediate embodiment of sickness as physiological process and its mediated (therefore meaning-laden) experience as human phenomenon - for example, as an alienated part of body-self, as a vehicle of transcendence, or as a source of 
embarrassment or grief' (Kleinman, 1988: 27). These insights, in turn, are augmented through Turner and Wainwright's (2003) recent embodied insights into the injured ballet dancer. Through a phenomenological understanding of the experiences of embodiment, these authors observe how injury and pain disrupt the practical accomplishments that underpin the ballet habitus and the dancer's identity. These very injuries, however, are themselves mediated through the social bonding of dancers into a professional ballet company, or corps de ballet, where injury is accepted as a sign of vocational commitment. A comprehensive account of injury amongst ballet dancers, therefore, would have to address: 'both the institutional and social settings of injury that construct the conditions under which injury is possible, and the embodiment of ballet practice that constitute the habitus of ballet ... major injury, such as a broken toe or damaged knee, can obviously terminate the career of a professional dancer at any point of time, but the translation of minor troubles into a serious injury is filtered through the social body of the dancers' (2003: 285).

Echoes of this viewpoint are increasingly evident in other recent attempts to bring impairment back into the disability debate. As writers such as Thomas (2002) argues, the social model of disability has been tremendously important in helping challenge the idea that the problems disabled people face are the inevitable, 'tragic' consequences of having impaired bodies. At one and the same time, however, this stance neglects the sometimes difficult realities of living with impairment: the 'eclipsing' of impairment, in effect, if not a mutual disengagement between disability studies and the sociology of the body (Hughes and Paterson, 1997). Disabled feminists in particular, Thomas notes, have been at the forefront of bringing the body in by drawing attention to impairment, thereby challenging the social model in which such matters are analytically left aside (see for example Crow, 1996; Wendell, 1996). A sociology of impairment, in this respect:

... needs to be able to engage with the real materiality of bodies whilst at the same time understanding the ways in which bodies are simultaneously always interpreted. Those of us who live with marked impairments know that the body is 'real' however thoroughly it is culturally represented and positioned. (Thomas, 2002: 77)

Shakespeare and Erickson (2000: 195) reach similar conclusions, stressing the need for a model that takes proper account of 'both the personal and physical experience of disability, and the social dimensions'. 'It needs too,' they continue, 'to recognise the importance of psychological processes and the cultural patterns and representations which influence the way we think about disabled people as disabled people.' These four, inextricably entwined dimensions, it is argued, 'produce the disability phenomenon which millions of people experience every day'. Zola's $(1982,1991)$ work too is another exemplar here, given his willingness to explore disability from many viewpoints, thereby attempting to link the material, social and cultural 
dimensions of disability in doing so. Processes of ageing moreover, Zola stressed, were something that linked the interests of the 'able-bodied' to those of the 'disabled'. The 'ontological reality of the impaired body', in short, from this perspective, is 'central to the development of any social theory of disability' (Williams and Busby, 2000: 182) - see also Freund's (2001) recent work on bodies, disability and spaces.

As for sociological work on death and dying, a more explicit engagement with the body has again been apparent here in recent years in various guises. Lawton's (2000) work on 'dirty' dying in the hospice, for instance, is a case in point, providing a graphic account of the corporeal dilemmas which particular types of dying pose. Her analysis in this respect, underlining the foregoing embodied themes, highlights the importance of focusing upon the 'real' body of the patient and the disease processes taking place within it and upon its surfaces - processes which, quite literally, led to the loss of bodily boundaries through the ravages of terminal cancer - in order to understand why some patients are sequestered within the hospice whereas others are not. By making the 'non-negotiable' deterioration of bodies of dying patients a central point of analysis, therefore, Lawton (2000:3) reveals how the capacity for mobility and for corporeal 'self-containment' are 'absolutely fundamental to selfhood in the modern "western" context'. In order for selfhood to be realized and maintained in contemporary society, in short, 'certain specific bodily capacities and attributes must be possessed: the most important being a bounded, enclosed body' (2000: 7).

What then of future agendas?

\section{Where do we go from here: back to the future?}

Despite these promising developments, much remains to be done, not simply in bringing the body back in (mission more or less accomplished), but in more explicitly addressing, debating, incorporating and theorizing the biological in doing so: a going beyond the biological, we might say, without leaving it out altogether. We are, in other words, at an early stage in this emerging or evolving 'material-corporeal' project, which attempts to 'marry' the biological and the social in a 'truly' embodied fashion (Newton, 2003a). A return to some basic (underlying or under-labouring) points, premises and principles may be useful therefore at this juncture, as a springboard to future discussion and debate.

Perhaps the first issue here is what, precisely, we mean by biology? This, to be sure, is a tricky issue. Biology, for example, may be viewed as both a set of living processes and animating principles (i.e. the biological or biologica), and a subject of scientific study (i.e. biology qua discipline); the former an ontological matter, the latter an epistemological matter, with complex relations between the two. Questions of the relationship between nature, biology and genetics complicate the picture further: itself requiring a fuller more systematic treatment in another paper. At the very least, I suggest, 
recourse to the biological (in the former sense), brings into play related issues to do with the materiality of organisms or bodies, and the 'brute' physical facts if not the fleshy dilemmas of our mortal existence.

There are, without doubt, many good reasons for past sociological distrust or scepticism regarding biology, in whatever guise. The biologisms of the recent past, for instance, could all be roundly condemned: 'philosophically, because they violated the logical distinction between facts and values; scientifically, because the genetic differences on the distribution of mental and moral traits among individuals and races appeared insignificant; and morally, because of the cruelties committed in their name' (Kaye, 1986: 2). Recourse to the biological, it seems, has all too often served dubious ends: called upon to legitimate inequalities and to limit freedom, particularly those of women, children and other 'marginalized' groups. So why invoke the biological? Surely social and cultural change outstrips biological evolution by far? Perhaps, but that in itself does not challenge the belief proposed by many advocates of neo-Darwinism, that any processes of social evolution are nonetheless constrained by earlier processes of biological evolution; a view linked to growing fascination with genetics, which has resurfaced in the popular guise of evolutionary psychology (EP). The dangers of a 'genes-eye' view of the world are all too apparent here, in keeping with other forms of reductionist thinking, both past and present (Higgs and Jones, 2003; Rose and Rose, 2000).

What is needed then, is not a retreat into former dualisms, nor a slide into any assimilation of sociology to biology or vice versa, but of (re)newed dialogue and debate of a more explicit kind. We need to recover or develop (new) non-reductionist ways of envisaging these relations in an attempt to go beyond any such yo-yo logic or either/or debate. On the one hand, to repeat, there are many promising signs here already, in medical sociology and beyond (see for example Benton, 1991,2003; Birke, 1999, 2003; Dickens, 2000; Freese et al., 2003; Goldman and Schurman, 2000; Pirani and Varga, 2005), ${ }^{3}$ not least, as we have seen, through recourse to issues of embodiment. On the other hand, to pronounce the problem solved is at best premature and at worst naïve, given the many unresolved issues and important challenges ahead (of which more later).

A realist perspective, I venture, has much to offer here as an underlabouring philosophy, helping us rethink the complexity of the world, and the biological and social relations contained therein, through non-reductionist principles of irreducibility and emergence conceived in 'open systems'. In doing so, moreover, not only is a robust defence mounted of structure-agency relationship and dynamics, but a 'weak' version of constructionism may also be readily accommodated, endorsed or incorporated; one that refuses to conflate ontological and epistemological matters (i.e. what we know and how we know it with what there is to know) (see for example, Archer et al., 1998; Sayer, 2000; Williams, 2003a). Shilling (2005), for example, in his own more recent writing on the body, proposes 
what he terms an explicit version of corporeal realism. Corporeal realism, it is argued, is distinct from its realist counterparts in as much as it treats the body-society relationship as its core problematic. At one and the same time, it is based on long-standing realist concepts concerning: (1) the ontologically stratified nature of the relationship between the social forces shaping society and the people who inhabit society; (2) the need for a temporal dimension to social analysis which enables the analysis of interaction over time of the generative properties of the body and the constraining forces of society in a non-reductionist or irreducible fashion; and (3) the potentially critical dimension of this form of social analysis or inquiry (2005: 12). The case, in short, for recognizing the body as an emergent, socially generative phenomenon is crucial or critical to this particular form of corporeal realism. The embodied subject, moreover, in keeping with realist commitments to irreducibility and emergence, is possessed not simply of physical attributes, important as they are, but of 'feelings, dispositions and embodied consciousness which emerges through evolution and development as an organism and which together enable humans to intervene and make a difference to their environment, to exercise agency' (2005: 13).

To this we may add a series of further important points which any such rethinking of the biological might profitably entertain, including an acknowledgement of biological enablements as well as constraints; a fuller, more subtle and nuanced account of the processual, dynamic, developmental nature of our lifelines, qua human organisms and embodied agents, involving the interplay of specificity and plasticity, being and becoming (Rose, 1997); and a recognition of the critical potential of the biological in exposing rather than legitimating oppressive social practices (helping us, in other words, to say what oppressive social practices are oppressive of and do damage to [Nussbaum, 1992; Sayer, 2000]). ${ }^{4}$ It may, indeed, be useful here to deconstruct the apparent unity of 'biology' as a disciplinary matrix and to think instead in terms of anatomy, physiology, neurobiology, endocrinology, genetics and so on, thereby reducing the risk of simplistic resolutions or realignments of biology and sociology. ${ }^{5}$ It is insights such as this, I venture, which may go some way toward giving the biological that albeit cautious welcome back in, which Benton (1991) called for over a decade ago now. It may also, as Birke (1999) comments, encourage us to delve more deeply 'into' bodies and their interior spaces, rather than remaining on the 'outside' or on the 'surface' (see, for example, Haraway, 1991, 1997;6 Martin, 1987, 1994). Realism, in short, if not corporeal realism or corporealism, has much to offer here. ${ }^{7}$ It also, to repeat, is compatible with a weak version of constructionism, or a radical realist version of constructionism if you prefer; a realist constructionism perhaps (Murphy, 2002). ${ }^{8}$

Medical sociology, to repeat, is (already) well placed to take up these challenges and carry these agendas forward in a variety of ways, from the role of biological and social factors in the 'afflictions' of health inequalities, 
to the vicissitudes of chronic illness, pain, disability, death and dying. Profitable intersections with debates in related fields such as the sociology of childhood (James et al., 2000; Mayall, 2002; Williams and Bendelow, 2003) and the sociology of ageing (Bury, 2000; Bury and Wadsworth, 2003; Williams, 2003b) underline these issues, as do other new domains of inquiry such as the sociology of sleep (Williams, 2002, 2003c, 2005). It is only by recognizing the 'ontological vulnerability' of the human body, including the 'tragic consequences of chronicity, impairment and disease', as Turner (2003: 280-1) rightly notes, that the social sciences can understand and contribute to the study of social suffering. In this way, he concludes, biology, via a 'secular theodicy' (i.e. problems of suffering and injustice) can 'usefully enter, or re-enter, the social sciences' (see also Turner and Rojek, 2001).

It is not simply a question, however, returning to the different aspects or dimensions of biology raised above, of rethinking biological factors, conceived as living animating processes and principles, but of rethinking the very relationship between sociology and the biological sciences themselves in doing so. The idea, as Bury (1997: 199) rightly comments, that such disciplines are only 'one way of understanding reality', discursive 'fabrications' or 'ideological edifices', 'underestimates the issues at stake and detracts from serious analysis'. If the body is to be invoked in sociological enquiry, he continues, and especially if (medical) sociology wishes to come to terms with 'corporeal realities', then 'the place of the biological sciences (as well as the biological dimensions of experience) has to be more clearly appreciated' (1997: 199-200). The state of the biological sciences, Benton reminds us, is 'fluid, there are numerous competing conceptualisations within biology, and there are several well-articulated alternatives to reductionist materialism available for use as philosophical means in the attempt to re-think the biology/society relationship' (1991: 18, emphasis added).

This is a call in effect, in the face of various (reductionist) brands or stands of sociologism, for a more 'mature' or 'balanced' form of sociological theorizing which recognizes the limits of our own knowledge (Craib, 1997; Williams, 2001, 2003b), while simultaneously acknowledging that other disciplines such as biology (or perhaps more correctly certain strands of non-reductionist thinking within it), do indeed have some important things to say about the world and our place within it. The constructionist tendency or temptation to turn other bodies of knowledge into mere 'fabrications' or objects of sociological scrutiny, critique or contempt, is thereby tempered, without abandoning it altogether. A weak form of constructionism, to repeat, has a place and is compatible with realist principles. Medical sociology, for instance, should indeed be able to challenge the biomedical monopoly over knowledge about the body, but superficial critiques - which throw the baby out with the bathwater - will not do. This is a position, in other words, which in no way trades our hard-won gains, or negates a robust defence of informed sociological critiques. 
Developments within the biological and medical sciences presage these issues in critical new ways through (global) processes of bio-medicalization and the like (Clarke et al., 2000, 2003). The new genetics (Conrad and Gabe, 1999), for example, not least 'reproductive genetics' (Ettorre, 1999), is raising a host of challenging new questions about what we take 'life' to be, what it is to be human, what 'counts' as the body, and where these and other limits lie (Katz Rothman, 1998). The implications of this in terms of relations between the body, identity and risk, including the impact of genetic knowledge on professional and lay views of chronic illness and disability, and its future role in the public's health, are also now very much on the agenda (see, for example, Kerr and Shakespeare, 2002; Petersen and Bunton, 2002; Shakespeare, 2003). These and other developments, in the era of bio-technology cum bio-capitalism, bio-prospecting, bio-patenting or bio-piracy (Scheper-Hughes and Wacquant, 2001), call it what you will, demand and necessitate a rethinking of relations between the biological and social sciences in ways which take us far beyond reductionism, whilst simultaneously tackling head on the social, ethical and political dilemmas this Brave New World of 'posthuman' (?) (Fukuyama, 2002) possibilities throws up: a process, as Clarke et al. appositely put it, with 'Western roots' and 'global rhizomes' - see also Frank's (2003) musings on alternative claims of posthuman futures.

This, however, is not the end of the story. Rethinking the biological also, of course, raises a series of red/green agendas concerning ecology and health, which extend far beyond the traditional remit or confines of medical sociology (Benton, 1991). Denying our evolutionary kinship and commonalities with other species, and our ecological responsibilities and interdependencies with other 'living and non-living forces and processes', from this viewpoint, is indeed unwarranted and unnecessary. One outcome of rethinking issues this way, as Benton (2003: 292) elegantly puts it, is to theorize social relations 'not simply as relations between social actors', but also as:

relations between human social actors and elements of non-human nature: physical objects and forces, artefacts, chemical substances, populations of cultivated, domesticated and wild varieties of species of non-human animals and plants, spatial envelopes, land and ecosystems, both modified and unmodified by past human activity, and so on. (See also Franklin, 2001; McLaughlin, 2001; Macnaghten and Urry, 2001; Murphy, 2002; Soper, 1995)

Rethinking biology in this way, to summarize, opens up a range of important, timely and topical issues that carry us from the dilemmas of embodiment, enselfment and emplacement (Turner, 2003), with or without the aid of the latest bio-technology cum bio-medicalization in the global era (Clarke et al., 2000, 2003; Turner, 2004), to the environmental, ecological and global agendas of the 21st century (Benton, 2003; Goldman and Schurman, 2000; York et al., 2003); themselves the site of collective as well as individual struggle and resistance. 


\section{The (un)knowable body: a further stumbling block?}

A number of problems and challenges remain, nonetheless, both theoretical and methodological, in any such project or undertaking. It is still very difficult, for example, as Newton (2003a) has recently commented, to 'know' or interrogate the biological dimensions of the body, at least with the conventional sociological toolkit. ${ }^{9}$ Many biological processes indeed remain unknown to us at the lived, embodied level (though the unconscious body, of course, "knows' them only too well). There is "no easy way to "know" the biological body', in other words, or to 'know how it relates to the social' (Newton, 2003a: 31-2). The differential temporal pace of biological and social processes, moreover, raises further problems. 'Culture, psyche and soma' in this respect remain 'intertwined', yet 'biological and social aspects of the body also represent the interweaving of different timescapes'. In trying to 'grapple' sociologically with the body therefore, Newton concludes, one is confronted with the difficulty of 'deriving a common epistemology across differing timescapes' (2003b: 450).

Does this then return us to something like a (back door) dualist position? Not necessarily. It is indeed quite possible, echoing Newton (2003b), to take an anti-dualist stance here that nonetheless acknowledges relative differences, if not divisions of this very kind. Acknowledging difference, in other words, is compatible or congruent with an anti-dualist position, though it may very well lead us to question an uncritical or unqualified commitment to, or endorsement of, narratives of 'wholeness' (Newton, 2003b: 434). Once you begin see the biological itself as a complex, multi-layered domain, moreover, there is the prospect of seeing patterns of similarities and differences between different domains (and the study of them) which do not all coincide with the 'biological'-'social' boundary or division. ${ }^{10}$

A return to the intellectual division of labour is also instructive at this point. Faced with these 'residual' problems, tensions and difficulties, Newton (2003a) suggests, material-corporeal sociologists may well have to learn some basic biology if they are truly to tackle these problems and move these agendas forward in profitable/productive ways. This may or may not be the case, particularly when charges of 'imperialism' are (rightly or wrongly) weighed in the balance. Either way, to repeat, the taking of a non-reductionist, irreducible position on these matters ensures that a robust defence of sociology is still possible. Calls for trans- or postdisciplinarity, in this respect, within or beyond the social sciences, may well be premature - see, for example, McLennan (2003) who endorses a limited form of trans-disciplinarity rather than post-disciplinarity - but this in no way precludes or prohibits the exploitation of profitable (problemcentred) bridgeheads as and where necessary or appropriate. As for consideration of the relationship between these specific issues, and broader questions of sociology's complexity (McLennan, 2003), I will leave that for others to debate. 
All in all, to summarize, we are clearly at an early stage in these developments, but we should not underestimate the challenges ahead if we are to achieve a 'truly' embodied sociology of the material-corporeal or corporealist kind, in health as elsewhere. Newton's comments and cautionary remarks, in this respect, are timely and topical, but in truth simply reinforce what most material corporeal sociologists already know and are actively grappling with; namely, that relations between the biological and the social are indeed complex, and that we need therefore to tread warily in this contested terrain, preparing ourselves for what would could in fact be a long journey, with many traps for the unwary en route.

\section{'Translating' the matter? Realizing the body in (medical) practice}

There is at least one further way forward here, however, in relation to the foregoing theme and issues, one only hinted at so far in the article. I am referring of course to what may loosely be termed the sociology of translation. Inspired by Latour (1993) and other like-minded thinkers within science and technology studies, this an 'impure' approach that effectively dispenses with sharp, clear-cut, neat and tidy modernist distinctions or division of the nature-culture kind in favour of a more mixed or hybrid view of the world. This is an approach, Prout (2000) comments, which remains both constructionist and materialist through its emphasis on hybridity and heterogeneity; a world which is produced in and through densely patterned networks of shifting associations and dissociations made up of a wide variety of human and non-human entities or 'quasi-objects' and 'quasi-subjects'. Analysis therefore concerns the 'translation' or networks of mediation between these different entities, all of which are treated as a priori equal or symmetrical actants, hence the other often-cited term for this approach, namely, actor network theory.

These ideas, for example, have recently been taken up to good effect within the sociology of childhood. Childhoods and bodies, in this respect, are placed in relation:

not only to symbolic but also material culture. What produces them is not simply biological events, not only the phenomenology of bodily experience, and not merely structures and symbols of discursive meaning - although all of these are important - but also patterns of material organization and their modes of order. (Prout, 2000: 15)

Examining childhood bodies therefore, from this perspective, becomes a matter of 'tracing through the means, the varied array of materials and practices involved in their construction and maintenance - and in some circumstances their unravelling and disintegration' (Prout, 2000: 15, emphasis added).

Place (2000), for instance, in a fascinating study of childhood bodies in a 
paediatric intensive care unit (PICU), shows how what is natural and what is social becomes hopelessly blurred in such settings. The definition of what precisely the corporeal elements of the (critically ill) child's body are, in other words, is very much open to negotiation here, given the manifold attachments of non-corporeal, technological elements vital for the child's survival, including processes of 'techno-dressing', which involve cannulation, intubation, catheterization and the placing of artefacts both inside and on the surface of the corporeal body: a 'socio-technological imbroglio', in effect. The contesting of such bodily boundaries, therefore, raises important questions as to the 'natural' status of children's bodies, redirecting attention instead to the notion that heterogeneity or hybridity is the norm or rule, including the mutual enrolment of the corporeal, the technological and the figurative (Place, 2000; Prout, 2000).

Another interesting variant on these themes is to be found in Mol's (2002) recent work on the 'body multiple' and the enactment of ontology in medical practice: a theoretically informed ethnography, to be more precise, of the diagnosis and treatment of atherosclerosis in a Dutch University Hospital, but with far wider implications for the issues raised in this article. Practice, indeed, is foregrounded here in a radical fashion. Again this represents another important shift away from the limits of constructionism or perspectivism, and the privileging of epistemological matters, to an inquiry focused squarely on the ways in which objects are enacted in practices (that is knowledge as a matter of manipulation rather than representation). It is not, in other words, a question here of different perspectives on the body and disease, or how medicine knows its objects, but of how medicine 'attunes to, interacts with, and shapes its objects' in and through its 'various and varied practices' (2002: vii). Ontologies, from this perspective, are far from transcendent. They are instead brought about or brought into being in practice. 'Reality', we are told, 'does not precede practices, but is part of them' (2002; 6; emphases in original). In practice, nonetheless, Mol argues, the body and its diseases are 'more than one', but without being fragmented into being many: a situation she tries to capture through the combination of a singular noun and a plural adjective, namely, the 'body multiple' - see also Mol and Law (2004). If practices are foregrounded in this way, in short:

... there is no longer a single passive object in the middle, waiting to be seen from the point of view of a seemingly endless series of perspectives. Instead objects come into being - and disappear - with the practices in which they are manipulated. And since the object of manipulation tends to differ from one practice to another, reality multiplies. The body, the patient, the disease, the doctor, the technician, the technology: all of these are more than one. More than singular. For even if objects differ from one practice to another, there are relations between these practices. Thus, far from necessarily falling into fragments, multiple objects tend to hang together somehow. Attending to the multiplicity of reality opens up the possibility of studying this remarkable achievement. (2002: 5) 
This 'praxiographic' approach, therefore, in keeping with the sociology of translation, requires us to take objects and events of all kinds into consideration: 'No phenomenon', indeed, 'can be ignored on the grounds that it belongs to another discipline' (Mol, 2002: 159). In a world where ontology is accepted to be multiple, realized quite literally in and through practice, the key question is 'what is being done, and what, in doing so, is reality in practice made to be' (2002: 159-60, emphasis added). This in turn becomes a political matter: a politics of what that 'includes ontology rather than presuming it' (2002: 184). If we hold to this notion that knowledge is primarily about 'partaking in a reality', moreover, then our understanding of relations between the sciences also 'begins to shift':

For whatever the relations between objects hidden inside the body - atherosclerotic plaque, peak flow velocity, increased cholesterol level - the practices in which these objects exist are concerned a lot more with expensive or cheap apparatus, blood or flesh, forms or conversations, work hours, self-esteem, insurance schemes. Treatment decisions are informed by the length of a stenosis and the length of hospital stay. In practice, such diverse phenomena do not belong to different orders. It makes no sense to delegate them to separate layers of reality. They are all relevant and somehow have to be reckoned with together. What different sciences have to offer practice is different points of leverage, different techniques of intervention, and, indeed, different methods. One specialism has dyes at its disposal, another knives, and a third the technique of humming, but in hospital practice they must somehow align and coordinate their objects. (2002: 154-5, emphasis added)

The sociology of translation and its 'offshoots' then, to summarise, provides another significant advance on a purely constructionist or representational approach to the body, or a purely anything approach for that matter; an 'impure' approach, to repeat, given the 'hybrid', material and cultural, human and non-human, world we live in. To the extent that sociomaterial practices are privileged or foregrounded in this way, moreover, we are powerfully reminded that reality is, in no small part or measure, an enacted matter (for example, ontology in practice). Perhaps most importantly, for our purposes, the implications of Mol's analysis, both in this text and her subsequent collaborative work (Mol and Law, 2004), seems to suggest that the 'coherence' of the body itself, or the way in which it 'hangs together', is far from axiomatic or self-evident. It is instead an on-going accomplishment or practical achievement: something, that is to say, that the embodied person needs to $d o$.

Problems remain nonetheless. The commitment within the sociology of translation to treating all human-non-human entities (or quasi-objects and quasi-subjects) as a priori equal or symmetrical actants, for example, is contentious to say the least. A nagging doubt also remains as to whether or not Mol overstates the case for multiplicity and the degree to which, as a corollary, the body and disease 'hang together' or 'cohere' through practice (that is 'coherence' as a practical accomplishment). Does Mol's 
emphasis on the enacted nature of reality in practice, moreover, laudable as it is, leave adequate room or grounding for the abiding nature of reality between or over and above any such practices? - see also Grosz (1994) for a similar concern with Butler's emphasis on performance; a term which Mol (2002: 41), admittedly, seeks to distance herself from. Here of course we return to the thorny question of whether or not ontologies are transcendent or brought about in practice. But we had better stop there.

\section{Conclusion}

Let me take this opportunity to restate here the central arguments upon which this article rests. If medical sociology, in keeping with the sociology of the body, is truly to face up to and work through the 'corporeal realities' of the body, emphasis on corporeal realities (Bury, 1997; Shilling, 2005), then it must at the very least entertain if not fully incorporate the biological as both a living set of animating forces and principles and a (legitimate) disciplinary form of knowledge - into its theorizing in ways we are only now beginning to profitably grapple with and address. This, to repeat, is not a call for reductionist thinking of any kind, sociological, biological or otherwise; we have had far too much of that already. Strong versions of constructionist thinking, on this count, are found wanting, like their biologically reductionist counterparts. Nor is it an attempt to dilute or detract from the hard-won gains and intellectual achievements of our discipline. It is instead, a call for new forms of thinking and new ways of theorizing these relations in non-reductionist, non-determinist terms which lay to rest the false starts and problems of the past in a spirit of renewed dialogue and debate. The article, in this respect, is part and parcel of a newly emerging 'materialcorporeal' (Newton, 2003a) project in sociology today. Realism, I have argued, has much to offer here as an under-labouring philosophy, particularly recent strands of corporeal realism (Shilling, 2005). So too does the sociology of translation, given its hybrid vision of the world based on the mutual enrolment or imbrication of the material and the cultural, the corporeal and the technological, the human and the non-human. The shift away from constructionism to the enactment of reality in and through sociomaterial practices, including the doing of the body as a practical accomplishment, adds further important insights and dimensions to this newly emerging corpus of work. My preference, however, to repeat, is for a straightforward material-corporeal version of realism of the kind elucidated, embodied or fleshed out above.

Medical sociology, it is clear, is well placed to address these issues. There are indeed, as we have seen, many promising signs here already, including recent studies in this material-corporeal vein on the expressive body, chronic illness, pain, disability, sleep, death and dying, alongside other recent work on the 'body multiple' and the enactment of (medical) reality in practice. Developments in biomedicine, bioscience and biotechnology, it has been 
argued, together with a series of red/green agendas concerning the political ecology as well as the political economy of health in the global era, presage these issues in critical new ways, demanding and necessitating a rethinking of biology-society relations. Whether or not this requires something akin to a 'new' medical sociology of course is a moot point. Certainly, as Turner (2004: 271) rightly argues, there is a need for a more comprehensive and sophisticated understanding of health and illness in the global era which recognizes that the 'major economic processes of modern society are concerned with the production of health through the pharmaceutical industry, research and development genetics, the integration of microbiology and information science, and the management of life processes, such as reproduction, ageing, and death'. Medicine, in this respect, is now a major component of the 'global economy' based on the 'production, reproduction, and the management of the human body' (2004: 272).

Herein lies a third conclusion then, namely, that it is not simply a question of what the sociology of the body can do for medical sociology but of what medical sociology, 'new' or 'old', can do for the sociology of the body. Medical sociology, as Bury (1997) comments, is not simply a means of illustrating sociological debates about the body and society, though it can of course do this quite successfully, but of evaluating them, contributing important new insights along the way. To the extent indeed that medical sociology is grounded or immersed in the existentially charged, morally laden, fleshy dilemmas and embodied predicaments of health and illness, pain and sickness, disease and disability, life and death, and to the extent that developments in biomedicine, bioscience and biotechnology constitute a critical point of sociological commentary or inquiry, then it may very well prove to be a 'leading edge', if not the leading edge (Turner, 1992), of contemporary theorizing about the body and society in a changing world. A 'new' medical sociology, moreover, which examines how macro processes of globalization, risk, economic deregulation and technological change shape and connect to personal embodied experiences of health and illness has much to offer both now and in the future (Turner, 2004).

This may all sound very promising - indeed it is - but important theoretical and methodological challenges still lie ahead and much remains to be done here on this material-corporeal front, not least, as I have already indicated, in terms of 'knowing' the (biological) body and in facing up to the complexity of relations between the biological and the social this entails, including their differential timescapes (Newton, 2003a, 2003b). Acknowledgement of important differences between biological and social process is still nonetheless, to repeat, congruent with an anti-dualist position on these matters. We are, to conclude, at an early stage in these developments and debates. Bringing the biological body back into our analysis, however, is no mere intellectual exercise. It is instead something that implicates us all, not simply as academics of this or that persuasion, but as embodied human beings, biologically vulnerable ones at that, with rights and responsibilities, 
both individual and collective in kind. The stakes are high. We neglect them at our peril.

\section{Notes}

1. Although mindful of these terminological issues and the history underpinning them, I will stick with the term 'medical sociology' throughout for the sake of consistency in this particular article.

2. 'Pristine' nature, Murphy (2002) argues, has been replaced by socially encompassed 'primal' nature, which retains its capacity for independent dynamics that affect social constructions. Technology socially constructed by humans, moreover, consists of a recombination of substances and processes created by nature's forces. Nature, nonetheless, can 'still surprise us', 'bite back' or 'escape our control'. Murphy, in short, steers a cautious and considered path between 'over-socialised' and 'under-socialised' views of nature. See also Franklin (2001) and Soper (1995) for useful discussions of these issues.

3. It is significant in fact, in this latter case, that Pirani and Varga (2005) are the editors of a special issue of the International Sociological Association journal Current Sociology on 'Bodily order. Mind, emotion and social memory', including a section specifically devoted to 'Biological body and cognitive processes'. The monograph, in this respect, seeks a 'dialogical approach' that aims to integrate the social and behavioural sciences within 'the living web of the developmental process' (Pirani and Varga, 2005: 190).

4. Sayer (2000) in fact goes further here, arguing, in the face of anti-essentialism, for a 'moderate', non-deterministic essentialism (vis-a-vis a strong deterministic essentialism); something, he claims, in keeping with the above observations, which is necessary for a social science with critical or emancipatory potential.

5. Thanks to one of the anonymous referees of this article for drawing this point to my attention.

6. Haraway's (leaky) position is not without its problems, however, particularly as far as information flows and the integrity of organisms as bounded entities are concerned. See Birke (1999) for example.

7. Shilling's own preferred term here is corporeal realism, rather than corporealism, on the grounds that the latter risks eliding a specific approach to the body with a general theoretical perspective (personal communication).

8. Freund (pers. comm.) wishes to speak of a radical version of constructionism here in the sense that it involves recognition of the fact that the social is not merely discursive and signals a programmatic intent to explore the reciprocal effects of the social on the biological or material and the biological or material on the social. Murphy's (2002: 321) notion of a 'realist constructionism' is a similarly intriguing and important one: 'the more social constructionism adopts a realist underpinning', he argues, 'the stronger it gets'.

9. Newton's (2003a) paper, in fact, is specifically targeted at those materialcorporeal sociologist for whom, in his view, the stress, emotion, health link is crucial. See Williams (2003d) for a rejoinder to these charges.

10. Thanks again to one of the anonymous referees of this article for drawing this point to my attention. 


\section{References}

Archer, M., Bhaskar, R., Collier, A., Lawson, T. and Norrie, A., Eds. (1998). Critical realism: Essential readings. London: Routledge.

Armstrong, D. (1983). Political anatomy of the body. Cambridge: Cambridge University Press.

Armstrong, D. (1995). The rise of surveillance medicine. Sociology of Health and Illness 17(3), 393-404.

Benton, T. (1991). Biology and social science: Why the return of the repressed should be given a (cautious) welcome. Sociology, 25(1), 1-29.

Benton, T. (2003). Ecology, health and society: a red/green perspective. In S.J. Williams, L. Birke and G. Bendelow (Eds.) Debating Biology: Sociological Reflections on Health, Medicine and Society, pp. 283-97. London: Routledge.

Birke, L. (1999). Feminism and the Biological Body. Edinburgh: Edinburgh University Press.

Birke, L. (2003). Shaping biology: Feminism and the idea of 'the biological', in S.J. Williams, L. Birke, and G. Bendelow (Eds.), Debating Biology: Sociological Reflections on Health, Medicine and Society, pp. 39-52. London: Routledge.

Blaxter, M. (2003). Biology, social class and inequalities in health: the synthesis in 'health capital'. In S.J. Williams, L. Birke and G. Bendelow (Eds.), Debating Biology: Sociological Reflections on Health, Medicine and Society, pp. 69-83. London: Routledge.

Boston Women's Health Collective (1973). Our bodies, ourselves. New York: Simon and Schuster.

Brown, G.W. and Harris, T.O., Eds. (1989). Life events and illness. London: Unwin Hyman.

Bury, M. (1986). Social constructionism and the development of sociology. Sociology of Health and Illness, 8(2), 137-69.

Bury, M. (1997). Health and illness in a changing society. London: Routledge.

Bury, M. (2000). Health, ageing and the lifecourse. In S.J. Williams, J. Gabe and M. Calnan (Eds.), Health, medicine and society: key theories, future agendas, pp. 87-106. London: Routledge.

Bury, M. and Wadsworth, M. (2003). 'The biological clock'. In S.J. Williams, L. Birke and G. Bendelow (Eds.), Debating Biology: Sociological Reflections on Health, Medicine and Society, pp. 109-20. London: Routledge.

Clarke, A., Mamo, L., Fishman, J., Shim, J. and Fosket, J.R. (2003). Biomedicalization: Technoscientific transformations of health, illness and US biomedicine. American Sociological Review, 68(April), 161-94.

Clarke, A., Fishman, J., Fosket, J., Mamo, L. and Shim, J. (2000). Technoscience and the new biomedicalization: Western roots, global rhizomes. Sciences Sociales et Sante, 18(2), 11-42.

Conrad, P. (1992). Medicalization and social control. Annual Review of Sociology, 18, 209-32.

Conrad, P. and Gabe, J. (1999). Introduction: Sociological perspectives on the new genetics: an overview. Sociology of Health and Illness, 21 (5), 505-16.

Craib, I. (1997). Social constructionism as social psychosis. Sociology, 31(1), 1-15.

Crow, L. (1996). Including all of our lives: renewing the social model of disability. In C. Barnes and G. Mercer G. (Eds.), Exploring the Divide: Illness and Disability, pp. 55-73. Leeds: The Disability Press. 
Deleuze, G. and Guattari, F. (1984). Anti-Oedipus: Capitalism and Schizophrenia I. London: Athlone Press.

Deleuze, G. and Guattari, F. (1989). A Thousand Plateaus: Capitalism and Schizophrenia II. London: Athlone Press.

Dickens, P. (2000). Social Darwinism. Buckingham: Open University Press.

Eckermann, L. (1997). Foucault, embodiment and gendered subjectivities: the case of voluntary self-starvation. In A. Petersen and R. Bunton (Eds.), Foucault and Health, pp. 131-72. London: Routledge.

Ettorre, E. (1999). Experts as 'storytellers' in reproductive genetics. Sociology of Health and Illness, 21(5), 539-59.

Fausto-Sterling, A. (1992). Myths of Gender: Biological theories about men and women, 2nd rev. edn. New York: Basic Books.

Fausto-Sterling, A. (2000). Sexing the body. New York: Basic Books.

Fausto-Sterling, A. (2003). The problem with sex/gender and nature/nurture. In S.J. Williams, L. Birke and G. Bendelow (Eds.), Debating biology: Sociological reflections on health, medicine and society, pp. 123-32. London: Routledge.

Foucault, M. (1973). The birth of the clinic. London: Tavistock.

Foucault, M. (1979) The history of sexuality vol. I. Harmondsworth: Penguin.

Fox, N. (1999). Beyond health: Postmodernism and embodiment. London: Free Association Books.

Frank, A.W. (1991) For a sociology of the body - An analytical review. In M. Featherstone, M. Hepworth and B.S. Turner (Eds.) The body: Social process, cultural theory. London: SAGE Publications.

Frank, A.W. (1995). The wounded storyteller: Body, illness and ethics. Chicago, IL: University of Chicago Press.

Frank, A.W. (1996). Reconciliatory alchemy: bodies, narrative and power. Body \& Society, 2, 53-71.

Frank, A.W. (2003). Bioethics and posthuman futures. In S.J. Williams, L. Birke and G. Bendelow (Eds.), Debating Biology: Sociological Reflections on Health, Medicine and Society, pp. 261-70. London: Routledge.

Franklin, A. (2001). Nature and social theory. London: SAGE Publications.

Freese, J., Li, J. and Wade, L.D. (2003) The potential relevances of biology to social inquiry. Annual Review of Sociology, 29, 233-56.

Freund, P.E.S. (1990). The expressive body: A common ground for the sociology of emotions and health and illness. Sociology of Health and Illness, 12(4), 452-77.

Freund, P.E.S. (2001). Bodies, disability and spaces: the social model of disability and disabling spatial organisations. Disability and Society, 16(5), 689-706.

Fukuyama, F. (2002). Our Posthuman Future. London: Profile Books.

Goldman, M. and Schurman, R. (2000). Closing the 'Great Divide': New social theory on society and nature. Annual Review of Sociology, 26, 563-84.

Grosz, E. (1994). Volatile bodies. Bloomington, IN: Indiana University Press.

Haraway, D. (1991). Simians, cyborgs and women. London: Free Association Books.

Haraway, D. (1997).Modest_Witness@Second_Millenium.

FemaleManc_Meets_OncoMouseTM. London: Routledge.

Harding, J. (1997). Bodies at risk: Sex, surveillance and hormone replacement therapy. In A. Petersen and R. Bunton (Eds.), Foucault and Health, pp. 134-50. London: Routledge.

Higgs, P. and Jones, I.R. (2003). Ultra-Darwinism and health: the limits to evolutionary psychology. In S.J. Williams, L. Birke and G. Bendelow (Eds.), 
Debating biology: Sociological reflections on health, medicine and society, pp. 27-38. London: Routledge.

Hughes, B. and Paterson K. (1997). The social model of disability and the disappearing body: towards a sociology of impairment. Disability \& Society, 12(3), 325-40.

Jacobus, M., Keller, E.F. and Shuttleworth S., Eds. (1990). Body/politics: women and the discourse of science. London: Routledge.

James, A., Jenks, C. and Prout, A. (2000). Theorizing childhoods. Cambridge: Polity Press.

Katz Rothman, B. (1998). Genetic maps and human imaginations: The limits of science in understanding who we are. New York and London: Norton \& Co.

Kaye, H.L. (1986). The social meaning of modern biology. New Haven, CT: Yale University Press.

Kelly, M. and Field, D. (1996). Medical sociology, chronic illness and the body. Sociology of Health and Illness, 18, 241-57.

Kerr, A. and Shakespeare, T. (2002). Genetic politics: From eugenics to genome. Cheltenham: New Clarion Press.

Kleinman, A. 1988: The illness narratives: Suffering, healing and the human condition. New York: Basic Books.

Latour, B. (1993). We have never been modern. Hemel Hempstead: Harvester Wheatsheaf.

Lawton, J. (2000). The dying process: Patients' experience of palliative care. London: Routledge.

Leder, D. (1990). The absent body. Chicago, IL: Chicago University Press.

Leder, D. (1998). A tale of two bodies: The Cartesian corpse and the lived body. In D. Welton (Ed.), Body and flesh: A philosophical reader, pp. 35-50. Oxford: Blackwell.

Lupton, D. (1997). Foucault and the medicalisation critique. In A. Petersen and R. Bunton (Eds.), Foucault, health and medicine, pp. 94-112. London: Routledge.

Macnaghten, P. and Urry, J., Eds. (2001). Bodies of nature. London: SAGE Publications.

Martin, E. (1987). The woman in the body. Milton Keynes: Open University Press.

Martin, E. (1994). Flexible bodies: The role of immunology in American culture from the age of polio to the age of AIDS. Boston, MA: Beacon Press.

Mayall, B. (2002). Towards a sociology for childhood. Milton Keynes: Open University Press.

McLaughlin, P. (2001). Toward an ecology of social action: Merging the ecological and constructivist traditions. Human Ecology Review, 8(2), 125-53.

McLennan, G. (2003). Sociology's complexity. Sociology, 37, 547-64.

Merleau-Ponty, M. (1962). The Phenomenology of Perception. London: Routledge and Kegan Paul.

Millward, L. and Kelly, M. (2003). Incorporating the biological: chronic illness, bodies, selves and the material world. In S.J. Williams, L. Birke and G. Bendelow (Eds.), Debating Biology: Sociological Reflections on Health, Medicine and Society, pp. 157-68. London: Routledge.

Mol, A. (2002). The body multiple: Ontology in medical practice. Durham NC: Duke University Press.

Mol, A. and Law, J. (2004). Embodied action, enacted bodies: the example of hypoglycaemia. Body \& Society, 10(2-3), 43-62. 
Monaghan, L. (2003). Civilised bodies: Incorporating the biological and the social. In S.J. Williams, L. Birke and G. Bendelow (Eds.), Debating Biology: Sociological Reflections on Health, Medicine and Society, pp. 145-56. London: Routledge.

Murphy, R. (2002). The internalization of autonomous nature into society. The Sociological Review, 50(3), 313-33.

Newton, T. (2003a). Truly embodied sociology: marrying the social and the biological? Sociological Review, 51(1), 20-42.

Newton, T. (2003b). Crossing the great divide. Sociology, 37(3), 433-57.

Nussbaum, M. (1992). Human functioning and social justice: in defence of Aristotelian essentialism. Political Theory, 20(2), 202-46.

Petersen, A. and Bunton, R. (2002). The new genetics and the public's health. London: Routledge.

Pirani, M. and Varga, I. (2005). Introducton: The ethics of complexity. Current Sociology, 52(2), 187-206.

Place, B. (2000). Constructing the bodies of ill children in the intensive care unit. In A. Prout (Ed.), The Body, Childhood and Society, pp. 172-94.

Prout, A. (2000). Childhood bodies: Social construction and translation. In S.J. Williams, J. Gabe and M. Calnan (Eds.), Health, medicine and society: Key theories, future agendas, pp. 109-22. London: Routledge.

Rose, H. and Rose, S., Eds. (2000). Alas poor Darwin: Arguments against evolutionary psychology. London: Jonathan Cape.

Rose, S. (1997). Lifelines: Biology, freedom and determinism. Harmondsworth: Penguin Books.

Sawiki, J. (1991). Disciplining Foucault: Feminism, power and the body. London: Routledge.

Sayer, A. (2000). Realism and social science. London: SAGE Publications.

Scheper-Hughes, N. and Wacquant, L.W., Eds. (2001). Commodifying bodies. London: SAGE Publications.

Shakespeare, T. (2003). Genetics and disabled people: rights, risks and responsibilities. In S.J. Williams, L. Birke and G. Bendelow (Eds.), Debating biology: Sociological reflections on health, medicine and society, pp. 198-209. London: Routledge.

Shakespeare, T. and Erickson, M. (2000). Different strokes: beyond biological determinism and social constructionism. In H. Rose and S. Rose (Eds.), Alas poor Darwin: Arguments against evolutionary psychology, pp. 190-205. London: Jonathan Cape.

Shilling, C. (2005). The body in culture, technology and society. London: SAGE Publications.

Soper, K. (1995). What is nature? Oxford: Blackwell.

Spelman, E. (1988). Inessential woman: Problems of exclusion in feminist thought. Boston, IL: Beacon Books.

Strong, P. (1979) Sociological imperialism and the medical profession. Social Science and Medicine, 13A, 199-215.

Tarlov, A.R. (1996). Social determinants of health: The sociobiological translation. In D. Blane, E. Brunner and R.G. Wilkinson (Eds.), Health and social organization: Towards a health policy for the 21st century, pp. 71-93. London: Routledge.

Thomas, C. (2002). The 'disabled body'. In M. Evans and E. Lee (Eds.), Real bodies, pp. 64-78. Basingstoke: Palgrave. 
Turner, B.S. (1992). Regulating bodies: Essays in medical sociology. London: Routledge.

Turner, B.S. (1995). Medical power and social knowledge (2nd Edition). London: SAGE Publications.

Turner, B.S. (1997). Foreword: From governmentality to risk: some reflections on Foucault's contribution to medical sociololgy. In A. Petersen and R. Bunton (Eds.), Foucault and Health, pp. ix-xxii. London: Routledge.

Turner, B.S. (2003) Biology, vulnerability and politics. In S.J. Williams, L. Birke and G. Bendelow (Eds.), Debating Biology: Sociological Reflections on Health, Medicine and Society, pp. 271-82. London: Routledge.

Turner, B.S. (2004). The new medical sociology: Social forms of health and illness. London/NY: W.W. Norton And Co.

Turner, B.S. and Rojek, C. (2001). Society and Culture: Principles of scarcity and solidarity. London: SAGE Publications.

Turner, B.S. and Wainwright, S. (2003). Corps de Ballet: The case of injured ballet dances. Sociology of Health and Illness, 25(4), 269-88.

Wendell, S. (1996). The rejected body: Feminist philosophical reflections on disability. London: Routledge.

Wilkinson, R.G. (1996). Unhealthy societies: The afflictions of inequality. London: Routledge.

Williams, G.H., and Busby, H. (2000). The politics of 'disabled' bodies. In S. Williams, J. Gabe and M. Calnan (Eds.), Health, medicine and society: Key theories, future agendas, pp. 169-85. London: Routledge.

Williams, S.J. (2001). Sociological imperialism and the medical profession revisited: where are we now? Sociology of Health and Illness, 23(2), 135-58.

Williams S.J. (2002). Corporeal reflections on the biological: Reductionism, constructionsm and beyond. In G. Bendelow, M. Carpenter, C. Vautier and S. Williams (Eds.), Gender, health and healing: the public/private divide, pp. 13-33. London: Routledge.

Williams, S.J. (2003a). Beyond meaning, discourse and the empirical world: Critical realist reflections on health. Social Theory and Health, 1(1), 42-71.

Williams, S.J. (2003b). Medicine and the body. London: SAGE Publications.

Williams, S.J. (2003c). Liminal bodies: sleep, death and dying. In S.J. Williams,

L. Birke and G. Bendelow (Eds.), Debating Biology: Sociological Reflections on Health, Medicine and Society, pp. 169-82. London: Routledge.

Williams, S.J. (2003d). Marrying the social and the biological? A reply to Newton. Sociological Review, 51(4), 550-61.

Williams, S.J. (2005). Sleep and society: Sociological ventures into the (un)known. London: Routledge.

Williams, S.J. and Bendelow, G. (1998). The lived Body: Sociological themes, embodied issues. London: Routledge.

Williams, S.J. and Bendelow, G. (2003). Childhood bodies: Constructionism and beyond. In S.J. Williams, L. Birke and G. Bendelow (Eds.), Debating Biology: Sociological Reflections on Health, Medicine and Society, pp. 133-44. London: Routledge.

York, R., Rosa, E.A. and Dietz, T. (2003). Footprints on the earth: The environmental consequences of modernity. American Sociological Review, 68(April), 279-300. 
health: 10(1)

Zola, I.K. (1982). Missing pieces: A chronicle of living with a disability. Philadelphia, PA: Temple

Zola, I.K. (1991). Bringing our bodies and ourselves back in: reflections on a past, present and future 'Medical Sociology'. Journal of Health and Social Behaviour, 32(March), 1-16.

\section{Author biography}

SIMON J. WILLIAMS is Reader in Sociology, University of Warwick. He has a longstanding interest in embodiment and health, including a recent book on Medicine and the body (2003), and a co-edited volume (with L. Birke and G. Bendelow) Debating biology: Sociological reflections on health, medicine and society (2003). His current research is centred around sleep, including a recent book, Sleep and Society: Sociological ventures into the (un)known (2005) and an ESRC seminar series on 'Sleep and Society' (http://www.warwick.ac.uk/go/sleepandsociety). He also has newly emerging research interests in citizenship, health and human rights in the global era. 